\title{
Biodegradation and Removal of PAHs by Bacillus velezensis Isolated from Fermented Food
}

\author{
Omme Fatema Sultana ${ }^{1 \dagger}$, Saebim Lee ${ }^{2 \dagger}$, Hoonhee Seo ${ }^{2}$, Hafij Al Mahmud ${ }^{2}$, Sukyung Kim ${ }^{2}$, \\ Ahyoung Seo ${ }^{2}$, Mijung Kim ${ }^{2}$, and Ho-Yeon Song ${ }^{1,2 *}$ \\ 'Department of Microbiology and Immunology, School of Medicine, Soonchunhyang University, Cheonan 31151, \\ Republic of Korea \\ ${ }^{2}$ Probiotics Microbiome Convergence Center, Soonchunhyang University, Asan 31538, Republic of Korea
}

\begin{abstract}
Polycyclic aromatic hydrocarbons (PAHs) are ubiquitous in the environment. They are highly toxigenic and carcinogenic. Probiotic bacteria isolated from fermented foods were tested to check their ability to degrade and/or detoxify PAHs. Five probiotic bacteria with distinct morphologies were isolated from a mixture of $\mathbf{2 6}$ fermented foods co-cultured with benzo(a)pyrene (BaP) containing Bushnell Haas minimal broth. Among them, B. velezensis (PMC10) significantly reduced the abundance of BaP in the broth. PMC10 completely degraded BaP presented at a lower concentration in broth culture. B. velezensis also showed a clear zone of degradation on a BaP-coated Bushnell Haas agar plate. Gene expression profiling showed significant increases of PAH ringhydroxylating dioxygenases and 4-hydroxybenzoate 3-monooxygenase genes in $B$. velezensis in response to $\mathrm{BaP}$ treatment. In addtion, both live and heat-killed $B$. velezensis removed $\mathrm{BaP}$ and naphthalene (Nap) from phosphate buffer solution. Live B. velezensis did not show any cytotoxicity to macrophage or human dermal fibroblast cells. Live-cell and cell-free supernatant of $B$. velezensis showed potential anti-inflammatory effects. Cell-free supernatant and extract of $B$. velezensis also showed free radical scavenging effects. These results highlight the prospective ability of $B$. velezensis to biodegrade and remove toxic PAHs from the human body and suggest that the biodegradation of BaP might be regulated by ring-hydroxylating dioxygenase-initiated metabolic pathway.
\end{abstract}

Keywords: PAH degradation, PAH removal, B. velezensis, fermented food, probiotics, ring-hydroxylating dioxygenase

Received: April 15, 2021 Accepted: May 20, 2021

First published online: May 21, 2021

* Corresponding author Phone: +82-41-570-2412 Fax: +82-41-577-2415 E-mail:songmic@sch.ac.kr

${ }^{\dagger}$ Omme Fatema Sultana and Saebim Lee contributed equally to this study.

pISSN 1017-7825 elSSN 1738-8872

Copyright(C) 2021 by The Korean Society for Microbiology and Biotechnology

\section{Introduction}

Polycyclic aromatic hydrocarbons (PAHs) are organic compounds made of two or more fused benzene rings [1]. PAHs are ubiquitous in the environment. They are usually formed by incomplete combustion of organic materials such as oil, coal, and gasoline. Due to their toxic, carcinogenic, and/or bioaccumulative nature, they can cause different diseases in the human body [2]. By changing or damaging genetic materials, PAHs can initiate the development of different cancers. Clinical studies have also shown PAHs' involvement in skin, stomach, liver, lung, bladder, and gastrointestinal cancers $[3,4]$. Among different PAHs, benzo(a)pyrene, benz(a)anthracene, dibenzo(a,l)pyrene, benzo(b)fluoranthene, benzo(k)fluoranthene, chrysene, dibenz(a,h)anthracene, indeno(1,2,3cd)pyrene, and naphthalene have been reported to be potent carcinogens by the Environmental Protection Agency (EPA) and other studies [4-7]. In addition, different mixtures comprising PAH compounds such as coal tar and vehicle exhaust have been reported by the International Agency for Research on Cancer as potential carcinogenic agents to humans [8]. Among them, benzo(a)pyrene and dibenz(a,h)anthracene have been reported to be the most carcinogenic [3]. Individuals can have both occupational and non-occupational exposure to PAHs through inhalation, ingestion, and dermal contact. A mixture of PAHs can also cause skin irritation and inflammation [9].

Probiotic bacteria are being used as beneficial agents for human health. They have been reported as a potential therapeutic option for degrading xenobiotics and removing toxic molecules $[1,10]$. Lactic acid bacteria (LAB) from a Japanese fermented food have binding affinities for heterocyclic amines [11]. Traditionally, LAB are used in the fermentation process in the food industry as beneficial microorganisms. They are also used as therapeutic agents for specific human diseases [12]. Although human clinical trials remain limited, probiotic bacteria are currently attracting much attention as anti-genotoxic and anti-mutagenic functional food [13]. Several probiotics 
have also been reported to be able to neutralize chemical-induced genotoxic or mutagenic effects [14]. To identify a potential safe probiotic candidate that could degrade or remove PAHs from the human body or food, we coincubated 26 Korean fermented foods with benzo(a)pyrene (BaP) for six successive 7-day incubations to find an effective probiotic that could degrade $\mathrm{BaP}$. Among hundreds of $\mathrm{PAHs}, \mathrm{BaP}$ is the best known and studied. It is frequently used as a PAH exposure marker [15]. Thus, we utilized $\mathrm{BaP}$ in the present study. Naphthalene is often used as a chemical model to study the PAH effect [16]. Thus, it was also selected in the present study. Isolated colonies were also subjected to GCMS analysis to evaluate BaP degradation efficacy. Additionally, expression levels of two enzymes, PAH ring- hydroxylating dioxygenases (PAH-RHDalpha) and 4-hydroxybenzoate 3monooxygenase (HBMO), were analyzed by qRT-PCR. These enzymes are involved in the initial step of aerobic metabolism of PAH [17]. In addition, the PAH-binding ability of the best candidate from the degradation experiment was evaluated in aqueous conditions. Functional effects such as anti-inflammatory and antioxidative effects of the selected probiotic candidate, B. velezensis, were also evaluated.

\section{Materials and Methods \\ Sample Selection}

In this study, we collected a total of 26 fermented foods from different parts of South Korea. These fermented foods could be classified into four different categories: fermented sauce $(n=18)$, $\operatorname{kimchi}(n=3)$, cheese $(n=3)$, and vinegar $(n=2)$. Samples were preserved at $4^{\circ} \mathrm{C}$ in the laboratory for further experiments.

\section{Enrichment and Isolation of PAH-Degrading Bacteria from Fermented Foods}

Each gram of 26 fermented foods was taken separately into a tube, added with $26 \mathrm{ml}$ of PBS, and mixed vigorously. Then, $5 \mathrm{ml}$ of the mixed food solution was transferred to $45 \mathrm{ml}$ Bushnell-Haas (BH) minimal medium containing $0.25 \%$ or $250 \mathrm{mg} / \mathrm{l}$ PAH (benzo(a)pyrene). The medium was supplemented with $5 \mathrm{ml}$ of trace metal solution and $100 \mu \mathrm{l}$ of vitamin solution per liter of media. The trace metal solution $(1 \mathrm{~L})$ in distilled water was prepared by mixing $200 \mathrm{mg}$ of $\mathrm{FeSO}_{4} \cdot 7 \mathrm{H}_{2} 0,10 \mathrm{mg}$ of $\mathrm{ZnSO}_{4} \cdot 7 \mathrm{H}_{2} 0,3 \mathrm{mg}$ of $\mathrm{MnCl}_{2} \cdot 4 \mathrm{H}_{2} 0,20 \mathrm{mg}$ of CoCl $2 \cdot 6 \mathrm{H}_{2} 0,1 \mathrm{mg}$ of $\mathrm{CuCl}_{2} \cdot 2 \mathrm{H}_{2} 0,2 \mathrm{mg}$ of $\mathrm{NiCl}_{2} \cdot 6 \mathrm{H}_{2} \mathrm{O}, 500 \mathrm{mg}$ of $\mathrm{Na}_{2} \mathrm{MoO}_{4} \cdot 2 \mathrm{H}_{2} 0$, and $30 \mathrm{mg}$ of $\mathrm{H}_{3} \mathrm{BO}_{3}$. A vitamin stock solution contained (per $100 \mathrm{ml}$ of distilled water) $2 \mathrm{mg}$ of biotin, $2 \mathrm{mg}$ of folic acid, $5 \mathrm{mg}$ of thiamine HCl, $5 \mathrm{mg}$ of D-calcium pantothenate, $5 \mathrm{mg}$ of vitamin B12, $5 \mathrm{mg}$ of riboflavin, $20 \mathrm{mg}$ of niacin, $3 \mathrm{mg}$ of pyridoxal $\mathrm{HCl}$, and $2 \mathrm{mg}$ of paraaminobenzoic acid [18]. Then, $15 \mathrm{~g}$ bacto (BD Difco, USA) agar was added, and the mixture was autoclaved to prepare Bushnell Haas agar (BHA).

PAH-degrading bacteria were isolated with a successive culture method, as reported earlier [19]. Briefly, mixed food samples were cultured in $\mathrm{BH}$ broth containing $0.25 \% \mathrm{PAH}$ as the sole carbon source and incubated at $37^{\circ} \mathrm{C}$ in a shaking incubator (100 rpm) for seven days. Next, $5.0 \mathrm{ml}$ of phase 1 culture was transferred to another $45 \mathrm{ml}$ fresh $\mathrm{BH}$ broth containing $0.25 \% \mathrm{PAH}$ and incubated for another week under similar conditions. This culture was repeated for another five consecutive times maintaining similar conditions to enable the bacteria to withstand the imposed stress.

\section{Identification of PAH-Degrading Bacteria by 16S rRNA Sequencing}

Bacteria that survived in the presence of $0.25 \% \mathrm{PAH}$ as a sole source of carbon were spread onto a nutrient agar plate. Following incubation at $37^{\circ} \mathrm{C}$, colonies with distinct morphologies were selected and stored at $-80^{\circ} \mathrm{C}$ for further experiment.

Distinct colonies were identified by $16 \mathrm{~S}$ rRNA gene sequencing. Genomic DNA was extracted and purified as previously described using a QIAamp DNA Mini Kit (Qiagen, Germany) following the manufacturer's protocol [20]. Universal primers 27F (5'-GAGAGTTTGATCCTGGCTCAG-3') and 1495R (5'-CTACGGCTACCTTGT TACGA-3') were used for 16S rRNA gene amplification and sequencing (Eurofins MWG Operon, Germany). Sequences were compared with those contained in the Ribosomal Database Project. Isolates were identified according to the Clinical and Laboratory Standards Institute (CLSI) guidelines [21] with an identity score of 99\%.

\section{Whole Genome Sequencing}

Genomic DNA was extracted from PMC10 using a QIAamp DNA Mini Kit (Qiagen) following the manufacturer's protocol. PacBio sequencing of the isolated genomic DNA was conducted at Chunlab Inc. (Korea). Obtained sequence data were assembled by PacBio SMRT Analysis 2.3.0 using HGAP2 protocol (Pacific Biosciences, USA). Finally, contigs obtained from the PacBio sequencing analysis were circularized using Circlator 1.2.0 (Sanger Institute, UK).

\section{Quantifying PAH Degradation by GCMS Analysis}

Isolated bacteria were inoculated into $\mathrm{LB}$ broth and incubated at $37^{\circ} \mathrm{C}$ overnight. The enriched culture was centrifuged at 4,000 $\mathrm{g}$ for $10 \mathrm{~min}$, and the pellet was re-suspended with $3 \mathrm{ml} \mathrm{BH}$ medium. Then $1,000 \mu \mathrm{l}$ of bacterial culture was added to $29 \mathrm{ml} \mathrm{BH}$ medium containing PAHs $(10 \mu \mathrm{g} / \mathrm{ml})$. After 20 days of incubation at $37^{\circ} \mathrm{C}$ in a shaking incubator, the concentration of PAHs was determined by GCMS analysis. Briefly, $n$-hexane was used as an extraction solvent and injected into the aqueous sample with acetone. The ratio of sample-to-extraction solvent was 1:10. Following 2 min of extraction, to break the emulsion, a second aliquot of acetone was injected into the solution as a demulsifier. The emulsion rapidly became clear and separated into two phases. The organic upper phase was collected and analyzed using an Agilent GC-5975C GC-MS system equipped with a Shimadzu AOC$20 \mathrm{i}$ autosampler and a DB-5ms (J\&W Scientific, USA) fused silica capillary column $(30 \mathrm{~m} \times 0.25 \mathrm{~mm}$ internal 
diameter (i.d.), $0.25 \mu \mathrm{m}$ film thickness). Helium with a purity of $99.9999 \%$ was employed as the carrier gas at a flow rate of $1.0 \mathrm{ml} / \mathrm{min}$. Next, $1 \mu \mathrm{l}$ of each sample was injected in a splitless mode $(10 \mathrm{ml} / \mathrm{min}, 1 \mathrm{~min})$. The injector temperature and interface temperature were maintained at 280 and $300^{\circ} \mathrm{C}$, respectively. Initially, the GC oven was held at $70^{\circ} \mathrm{C}$ for $2 \mathrm{~min}$ and then shifted to $190^{\circ} \mathrm{C}$ at $15^{\circ} \mathrm{C} / \mathrm{min}$. Following holding at $190^{\circ} \mathrm{C}$ for $1 \mathrm{~min}$, the oven was programmed to $260^{\circ} \mathrm{C}$ at $10^{\circ} \mathrm{C} / \mathrm{min}$. Finally, it was programmed to $285^{\circ} \mathrm{C}$ at $5^{\circ} \mathrm{C} / \mathrm{min}$ and held for $5 \mathrm{~min}$. The solvent cut time was $6 \mathrm{~min}$. Masses monitored by the detector were set as follows: $(6-8) \mathrm{min}, \mathrm{m} / \mathrm{z}(128,129,127$, 102); (8-9.5) $\mathrm{min}, \mathrm{m} / \mathrm{z}(152,153,151,154) ;(9.5-10.8) \mathrm{min}, \mathrm{m} / \mathrm{z}(166,165,167,139) ;(10.8-13) \mathrm{min}, \mathrm{m} / \mathrm{z}(178,176$, $179,152) ;(13-16) \mathrm{min}, \mathrm{m} / \mathrm{z}(202,203,200,101) ;(16-20) \mathrm{min}, \mathrm{m} / \mathrm{z}(228,226,229,227,252) ;(20-23) \mathrm{min}, \mathrm{m} / \mathrm{z}$ $(253,252,250,126) ;(23-28) \mathrm{min}, \mathrm{m} / \mathrm{z}(276,278,277,138)$. PAH standards and samples were analyzed in selective ion monitoring (SIM) mode for quantitative determination of analytes: Nap, m/z (128, 129, 127, 102); Acp, m/z (152, 153, 151); Ace, m/z (153, 154, 152); Flu, m/z (166, 165, 167); Phe, m/z (178, 176, 179); Ant, m/z (178, 179, 176); Flt, m/z (202, 203, 200, 101); Pyr, m/z (202, 200, 203, 101); Cry, m/z (228, 226, 229); BaA, m/z (228, 226, 227, 229, 252); BbF, m/z (252, 253, 250); BkF, m/z (252, 250, 126); BaP, m/z (252, 253, 250, 126); InP, m/z, (276, 277 , 138); DBA, $\mathrm{m} / \mathrm{z}(278,276)$; and BghiP, $\mathrm{m} / \mathrm{z}(276,277,138)$.

\section{Evaluating BaP Degradation Using ELISA}

PMC10 was inoculated into $\mathrm{LB}$ broth and incubated at $37^{\circ} \mathrm{C}$ overnight. The overnight grown culture was centrifuged at 4,000 $\mathrm{g}$ for $10 \mathrm{~min}$, and the pellet was re-suspended in $3 \mathrm{ml} \mathrm{BH}$ medium. Then 1,000 $\mu \mathrm{l}$ of the bacterial culture was added to $29 \mathrm{ml} \mathrm{BH}$ medium containing BaP at $100 \mathrm{ng} / \mathrm{ml}$. After 20 days of incubation at $37^{\circ} \mathrm{C}$ in a shaking incubator, the concentration of $\mathrm{BaP}$ was determined using an ELISA kit (Benzo(a)Pyrene ELISA, Creative Diagnostics, USA) following the manufacturer's protocol. Briefly, $50 \mu$ l of the standard solution or sample was added to the wells of test strips. Then, $50 \mu \mathrm{l}$ of the enzyme conjugate solution was added to individual wells followed by the addition of $50 \mu \mathrm{l}$ of antibody solution. Following a brief circular motion, strips were incubated at 4 $8^{\circ} \mathrm{C}$ for $60 \mathrm{~min}$. After incubation, strips were washed three times using $1 \mathrm{X}$ washing buffer solution. Strips were then incubated at room temperature for $30 \mathrm{~min}$ following the addition of $100 \mu \mathrm{l}$ of substrate/color solution to each well. After incubation, $50 \mu \mathrm{l}$ of stop solution was added to each well, and absorbance was measured at $450 \mathrm{~nm}$ using a microplate ELISA photometer within $15 \mathrm{~min}$.

\section{Checking Clear Zones Formed by PAH Degrader}

$\mathrm{BaP}$ degradation test was performed by observing the formation of a clear zone around isolated colonies from a $\mathrm{BaP}$-containing broth culture on a BaP-coated plate. Briefly, $200 \mu \mathrm{l} \mathrm{of} 10 \mathrm{mg} / \mathrm{ml} \mathrm{BaP}$ in acetone was spread onto Bushnell Haas minimal agar plate supplemented with trace metal and vitamins. A well was made with or without a $\mathrm{BaP}$-containing $\mathrm{BH}$ agar. Then, $50 \mu \mathrm{l}$ of full-grown bacterial culture was inoculated into the well and incubated at $37^{\circ} \mathrm{C}$ for 20 days. Degradation of $\mathrm{BaP}$ was recognized by clear zone formation.

\section{In Vitro PAH Binding Assays}

PAH binding assays were performed following a previous report [1]. Briefly, $2 \mathrm{ml}$ of full-grown bacterial culture $\left(\sim 10^{9} \mathrm{CFU} / \mathrm{ml}\right)$ in $\mathrm{LB}$ was centrifuged at $4,000 \mathrm{~g}$ for $15 \mathrm{~min}$ and washed with phosphate-buffered saline (PBS) twice. Finally, the bacterial pellet was suspended in $2 \mathrm{ml}$ of PBS containing $10 \mu \mathrm{g} / \mathrm{ml}$ PAHs. Following shaking, the solution was kept at $37^{\circ} \mathrm{C}$ for $10 \mathrm{~h}$ in a shaking incubator. The PBS was maintained at $\mathrm{pH} 5$.

In this study, PBS plus PAH solution was used as a positive control. Following incubation, bacteria were separated by centrifugation. The amount of unbound PAHs in the cell-free supernatant was then measured using GCMS. In the case of dead bacteria, bacterial culture $\left(\sim 10^{9} \mathrm{CFU} / \mathrm{ml}\right)$ was autoclaved at $121^{\circ} \mathrm{C}$ for $15 \mathrm{~min}$ and then centrifuged at $4,000 \mathrm{~g}$ for $15 \mathrm{~min}$. After PBS washing, the experiment was done following the same protocol used for live bacteria.

\section{Total RNA Extraction and qRT-PCR}

First, $30 \mathrm{~mL}$ of an overnight grown culture of B. velezensis was treated with $20 \mu \mathrm{g} / \mathrm{ml} \mathrm{BaP}$ and incubated for 0,24 , and $48 \mathrm{~h}$ at $37^{\circ} \mathrm{C}$. Following incubation, total RNA was extracted using an RNeasy Mini Kit (Qiagen) following the manufacturer's instructions. Next, cDNA was prepared using an iScriptTMcDNA Synthesis Kit (Bio-Rad) and stored at $-20^{\circ} \mathrm{C}$ for further study.

To investigate the relative gene expression levels of PAH ring-hydroxylating dioxygenase alpha subunit (RHDa) and 4-hydroxybenzoate 3-monooxygenase in response to $\mathrm{BaP}$, a set of primers was used (Table 1). These primers

Table 1. List of primers used in this study for qRT-PCR.

\begin{tabular}{llc}
\hline Primer & \multicolumn{1}{c}{ Sequence 5'-3' } & Amplicon size (bp) \\
\hline RHDa Fw & GGA AAG GCT TGT GGG TGT CG & 252 \\
RHDa Re & GTG GCA TCA TCG CAT CGT GT & 157 \\
HBMO Fw & GCG TGT GCC GCC TTG TAA TCA & \\
HBMO Re & ACG CCA GTT CGT CCC AGA TGC & 433 \\
$16 \mathrm{~S}$ Fw & AAC GCG AAG AAC CTT AC \\
$16 \mathrm{Se}$ & CGG TGT GTA CAA GAC CC & \\
\hline
\end{tabular}

Fw, Forward primer; Re, Reverse primer; RHDa, ring-hydroxylating dioxygenase alpha subunit; HBMO, 4-hydroxybenzoate 3monooxygenase. 
were obtained from a previous report [17]. Relative levels of genes were determined by qRT-PCR, which was performed in a $20 \mu \mathrm{l}$ reaction mixture. This reaction mixture contained $4 \mu \mathrm{l}$ nuclease-free water, $10 \mu \mathrm{l}$ SYBR Green Supermix (Bio-Rad), $5 \mu \mathrm{l}$ cDNA, and $0.5 \mu \mathrm{l}$ of each primer $(10 \mu \mathrm{M})$. PCR was conducted with the following temperature profiles: activation at $95^{\circ} \mathrm{C}$ for $10 \mathrm{~s}$, followed by 50 cycles of $95^{\circ} \mathrm{C}$ for $10 \mathrm{~s}, 58^{\circ} \mathrm{C}$ for $45 \mathrm{~s}$, and elongation at $72^{\circ} \mathrm{C}$ for $30 \mathrm{~s}$. Endogenous control gene $16 \mathrm{~S}$ was used to normalize gene expression levels.

Preparation of Cell-Free Culture Supernatant (CFS) and Intracellular Cell-Free Extracts (CFE)

CFS and CFE were prepared as described previously [22] with a slight modification. Briefly, cultures of probiotic strains $\left(\sim 10^{9} \mathrm{CFU} / \mathrm{ml}\right)$ were centrifuged at $10,000 \mathrm{~g}$ for $10 \mathrm{~min}$. Following centrifugation, the supernatant was filtered using a $0.22 \mu \mathrm{m}$ pore size filter. The filtered supernatant was used for further study. To prepare intracellular cell-free extracts, bacterial cells were washed twice with deionized water. Following washing, cells were suspended in deionized water. These cells were then subjected to bead beating for $1 \mathrm{~min}$ to break cell walls. Following centrifugation at 7,800 $\mathrm{g}$ for $10 \mathrm{~min}$, cell debris was removed and the supernatant was used as an intracellular cell-free extract for further experiment.

\section{Cells and Culture Conditions}

Mouse macrophage RAW 264.7 cells were purchased from the American Type Culture Collection (ATCC, USA) and cultured in Dulbecco's Modified Eagle's Medium (DMEM) supplemented with $10 \%(\mathrm{v} / \mathrm{v})$ heatinactivated fetal bovine serum (FBS) and $1 \%(\mathrm{v} / \mathrm{v})$ antibiotic/ antimycotic cocktail at $37^{\circ} \mathrm{C}$ with $5 \% \mathrm{CO}_{2}$. Cells were seeded into 96-well plates at a density of $\sim 1 \times 10^{4}$ cells/well and incubated at $37^{\circ} \mathrm{C}$ with $5 \% \mathrm{CO}_{2}$ for $24 \mathrm{~h}$. Human dermal fibroblast cells were purchased from the American Type Culture Collection (ATCC, USA) and maintained in Fibroblast Basal Medium (FBM) (Lonza; CC-3131) supplemented with FGMTM-2 SingleQuotsTM supplements (CC-4126) which included $0.50 \mathrm{ml}$ insulin, $0.50 \mathrm{ml}$ hFGF-B (human fibroblastic growth factor), $0.50 \mathrm{ml}$ GA-1000 (Gentamicin sulfate-Amphotericin), and $10.00 \mathrm{ml}$ FBS (heat-inactivated fetal bovine serum). Cells were maintained in a humidified atmosphere at $37^{\circ} \mathrm{C}$ with $5 \% \mathrm{CO}_{2}$, seeded into 96 -well plates at a density of $\sim 1 \times 10^{5}$ cells/well, and cultured for $24 \mathrm{~h}$.

\section{Cell Viability Assay}

Cell viability assay was performed to determine the cytotoxic effects of probiotic bacteria on RAW 264.7 macrophages and human dermal fibroblast cells. This assay was based on the conversion of a colorless, transparent 3-(4, 5-dimethylthiazol-2-yl)-2, 5-diphenyltetrazolium bromide (MTT) salt into a purple formazan crystal by mitochondrial dehydrogenase of live cells. Following $24 \mathrm{~h}$ of incubation, RAW 264.7 and HDF cell monolayers were seeded into 96-well plates, treated with probiotic bacteria at $1 \sim 0^{5}$ or $\sim 10^{7} \mathrm{CFU} / \mathrm{ml}$, and incubated at $37^{\circ} \mathrm{C}$ with $5 \% \mathrm{CO}_{2}$ for another $24 \mathrm{~h}$. Following incubation, $50 \mu \mathrm{l}$ of $2 \mathrm{mg} / \mathrm{ml} \mathrm{MTT} \mathrm{solution} \mathrm{was} \mathrm{added} \mathrm{to} \mathrm{each} \mathrm{well} \mathrm{and}$ incubated for a further $4 \mathrm{~h}$ at $37^{\circ} \mathrm{C}$. After incubation, media were removed completely from the plate and $100 \mu \mathrm{l}$ of DMSO was added to each well. Plates were then incubated at $37^{\circ} \mathrm{C}$ for 10 to $15 \mathrm{~min}$ to dissolve the formazan crystal. Absorbance was measured at $570 \mathrm{~nm}$ using a Victor $\times 3$ Multilabel Reader (Perkin Elmer 2030, USA) following $5 \mathrm{~min}$ of incubation in a shaker at room temperature (RT).

\section{Determination of Anti-Inflammatory Activity of Probiotic Bacteria in RAW 264.7 Macrophages}

Cells were seeded into 96 -well plates at a density of $\sim 1 \times 10^{4}$ cells/well and incubated at $37^{\circ} \mathrm{C}$ with $5 \% \mathrm{CO}_{2}$ for $24 \mathrm{~h}$. Following incubation, media were removed from the plate and the cell monolayer was treated with the selected probiotic strain at $\sim 10^{5}$ or $\sim 10^{7} \mathrm{CFU} /$ well in DMEM without antibiotics for $12 \mathrm{~h}$. As for the case cell-free supernatant (CFS) of the probiotic bacteria, the RAW 264.7 cell monolayer was treated with $10 \%$ or $20 \%$ of CFS in DMEM for $12 \mathrm{~h}$. Following incubation, RAW 264.7 cells plus probiotics were exposed to 2,000 $\mathrm{ng} / \mathrm{ml}$ lipopolysaccharide (LPS) for $24 \mathrm{~h}$. After incubation, the production of nitric oxide (NO) was measured using Griess reagent (Sigma Aldrich, USA) following the manufacturer's instructions. Briefly, $50 \mu \mathrm{l}$ of the culture supernatant was transferred to a new plate. Then, $50 \mu \mathrm{l}$ of Griess reagent was added. After 1 min of mixing in a shaker, the plate was incubated at $37^{\circ} \mathrm{C}$ for $15 \mathrm{~min}$. Absorbance was measured at $540 \mathrm{~nm}$ using a Victor $\times 3$ Multilabel Reader (Perkin Elmer 2030).

\section{Measuring DPPH-Free Radical Scavenging Activity}

In this experiment, probiotic cell-free supernatant and cell-free extract were used as assay samples. The DPPHfree radical scavenging activity of each sample was measured by following the procedure described earlier [22]. Briefly, $0.8 \mathrm{ml}$ of each sample was added with $2.2 \mathrm{ml} \mathrm{DPPH}$-free radical $(0.1 \mathrm{mM})$, mixed vigorously, and then kept in the dark for $30 \mathrm{~min}$ at RT. Finally, the absorbance was measured at $517 \mathrm{~nm}$. Deionized water was used as a blank control sample. The DPPH-free radical scavenging activity was calculated using the following equation:

Scavenging effect $(\%)=[1$ - A517 (sample) $/$ A517 (blank) $] \times 100$.

\section{Statistical Analysis}

Every experiment was repeated at least three times. Student's $t$-test was used to evaluate the statistical significance of results of different experiments using GraphPad Prism 7 software. In the graph, data are presented as mean \pm SD. Means were considered to be significant at $p<0.05$ and marked with asterisks $\left({ }^{*} p<0.05 ;{ }^{* *} p<0.01\right.$; ${ }^{* * *} p<0.001$; and $\left.{ }^{* * *} p<0.0001\right)$. 
Table 2. Identification of isolated bacterial strain based on 16S rRNA gene sequence analysis.

\begin{tabular}{cllccc}
\hline \multirow{2}{*}{ Rank } & \multicolumn{1}{c}{ Name } & Strain & $\begin{array}{c}\text { Pairwise } \\
\text { similarity (\%) }\end{array}$ & $\begin{array}{c}\text { Different nt/ } \\
\text { Total nt }\end{array}$ & $\begin{array}{c}\text { Completeness } \\
(\%)\end{array}$ \\
\hline 1 & Bacillus velezensis & CR-502 & 99.92722 & $1 / 1374$ & 95.38043 \\
2 & Bacillus velezensis subsp. subtilis & KCTC 13613 & 99.78571 & $3 / 1400$ & 100 \\
3 & Bacillus siamensis & CR-502 & 99.78571 & $3 / 1400$ & 100 \\
4 & Bacillus amyloliquefaciens & DSM 7 & 99.64286 & $5 / 1400$ & 100 \\
5 & Bacillus tequilensis & KCTC 13622 & 99.57143 & $6 / 1400$ & 100 \\
\hline
\end{tabular}

\section{Results}

\section{Identification of PAH-Degrading Bacteria Based on 16S rRNA Gene Sequence Analysis}

From an initial screening with bacteria isolated from 26 different fermented foods, five bacterial strains (PMC1, PMC2, PMC3, PMC10, and PMC12) showed PAH-degrading efficacy (data not shown here). Molecular assays were conducted to identify these five strains. To establish the identity and classification of newly isolated bacteria, 16S rRNA gene sequences are common genetic markers frequently used in phylogeny and taxonomy [23, 24]. They are also widely used to study the taxonomic relationship between different microorganisms. Sequence similarity of $98.65 \%$ is considered as the cut-off value for delineating species [20, 23]. Thus, 16S rRNA gene sequence of PMC10, a PAH-degrading isolate, was compared with the reference sequence database from the National Center for Biotechnology Information (NCBI). PMC10 was identified as Bacillus velezensis (Table 2). This isolate shared more than $99 \%$ sequence similarity with its various closest relative. It showed maximum similarity (99.93\%) with Bacillus velezensis CR-502. However, $16 \mathrm{~S}$ rRNA gene sequence information is not always adequate to confirm bacterial identity at the genus level. Therefore, we conducted an extensive whole-genome sequence analysis to identify the exact species of the selected strain.

\section{Revealing the Identity of PMC10 by Comparative Genomic Analysis}

Genomic analysis revealed that PMC10 possessed a single, circular chromosome of 4,031,530 bp, with an average GC content of $46.1 \%$ (Fig. 1). The PMC10 genome had around 4,077 coding sequences (CDSs) with an average length of $873.4 \mathrm{bp}$ (Fig. 1A). Coding sequences were grouped into different Orthologous Group (COG) clusters based on functional prediction (Fig. 1B). A total of 3,680 proteins were assigned to COG families among these CDSs [25]. Among these proteins, biological functions were predicted for 2,549 or $62.5 \%$ of identified proteins. A total of 1131 CDS (27.7\%) were found to be homologous to conserved proteins in other organisms with unknown functions. In addition, 397 (9.7\%) of identified CDSs did not match with any proteins in the database with known functions. Therefore, they were defined as hypothetical proteins. Genomic analysis also predicted about 78 tRNA and 24 rRNA genes.

For robust and faster taxonomic identification, OrthoANI is a widely used bioinformatics tool for calculating average nucleotide identify [26]. Whole genome sequence data of PMC10 were used to identify shared similarities between strains using OrthoANI (Fig. 2). Results of OrthoANI analysis revealed that the isolated strain PMC10 shared $99.05 \%$ similarities with the genome of B. valenzesis strains (DKU_NT_04), 97.95\% similarity with $B$. velezensis (strain B5), and $98.05 \%$ similarity with B. velezensis (CBMB205). The similarity percentage was significantly higher than the cut-off value of $95 \%$ for species delineation [27]. On the other hand, isolate PMC10 shared very lower similarities (less than 77.50\%) with other Bacillus tequilensis genomes. These results of genomic analyses suggest that this PAH-degrading isolate PMC10 is B. valenzensis, similar to the 16S rRNA gene sequencing result.

Genome features of PMC10 (B. velezensis) were then compared with other publicly available genomic information of different B. velezensis strains (9D-6, UFLA258, NST6 and AL7) (Table 3). Although all strains belonged to the same species, their genome sizes, GC contents, and numbers of CDS, rRNA, and tRNA, were very different. These data suggest that PMC10 is a new strain of B. velezensis. The draft genome sequence of strain PMC10 will further guide us to unveil the molecular mechanism involved in PAH degradation by PMC10.

\section{Degradation of BaP in Broth Culture and Agar Medium}

The BaP degradation abilities of isolates PMC1, PMC2, PMC3, PMC10, and PMC12 were evaluated using $50 \mathrm{ml} \mathrm{BH}$ broth containing $10 \mu \mathrm{g} / \mathrm{ml} \mathrm{BaP}$ as the sole source of carbon. Following 20 days of incubation with or without a test strain, the concentration of the polyaromatic hydrocarbon in the broth culture was measured by

Table 3. Comparison of genome features of Bacillus velezensis strains.

\begin{tabular}{lccccc}
\hline \multicolumn{1}{c}{ Strains } & PMC10 & 9D-6 & UFLA258 & NST6 & AL7 \\
\hline Genome size (bp) & $4,031,530$ & $3,960,000$ & $3,947,620$ & $4,141,240$ & $3,894,709$ \\
G+C content (\%) & 46.1 & 46.5 & 46.5 & 46.04 & 46.64 \\
Predicted CDS & 4,077 & 3849 & 3,747 & 4070 & 3706 \\
Number of rRNA genes & 24 & 21 & 116 & 27 & 27 \\
Number of tRNA genes & 78 & 68 & & 86 & 86 \\
References & & {$[43]$} & {$[44]$} & {$[45]$} & {$[46]$} \\
\hline
\end{tabular}


A

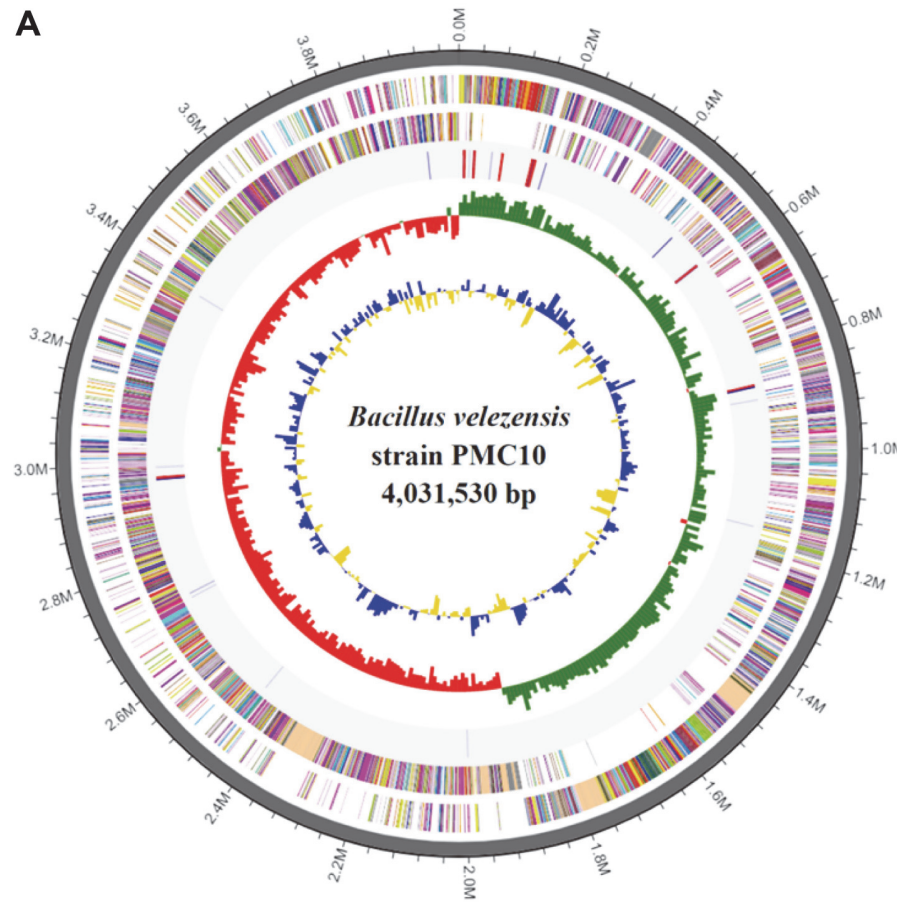

B

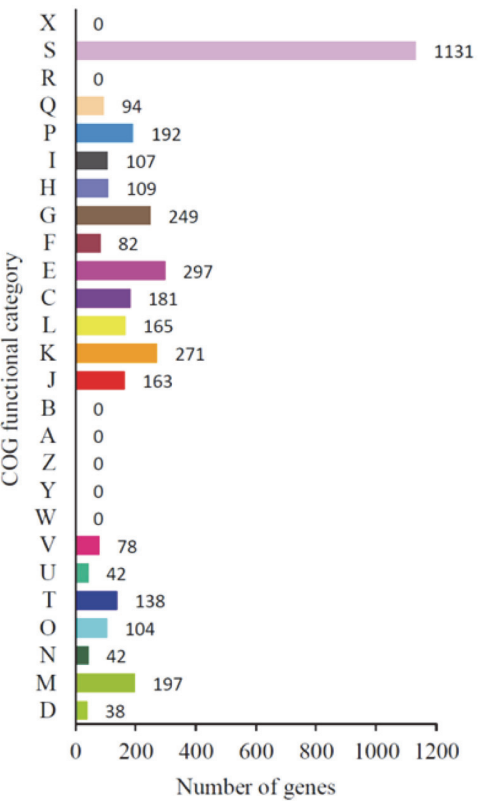

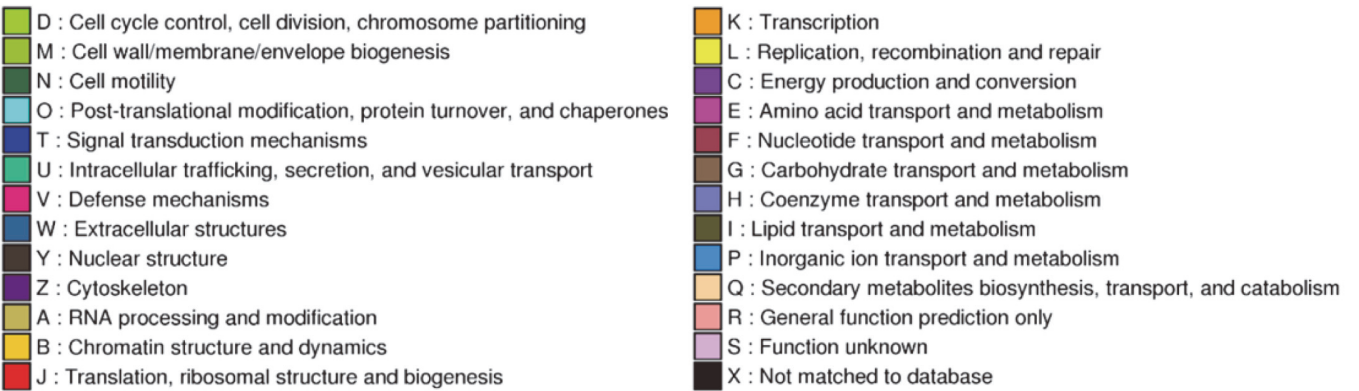

Fig. 1. Identification of PMC10 through high-throughput whole genome sequencing. (A) Circular map of Bacillus velezensis strain (PMC10) genome. Antisense and sense strands are colored according to COG categories and placed in the outermost ring. RNA genes are shown next to antisense and sense strands from the outside where tRNA and rRNA are shown as red and blue, respectively. Inner circles present GC skew. Yellow indicates positive values and blue indicates negative values. GC content is showed in red and green. CLC genomics was used to visualize the genome map. (B) Relative number of clusters of orthologous groups (COG) based on functional gene categories.

GCMS analysis. Changes in $\mathrm{BaP}$ concentration in the test cultures were compared with control experiments lacking the probiotic strain. According to GCMS data, PMC10 resulted in the highest reduction in the concentration of $\mathrm{BaP}$ after 20 days of incubation among all strains tested. It reduced $51.32 \%$ of the dissolved $\mathrm{BaP}$ compared to the control group (Fig. 3A).

To confirm the effect of PMC10 as a BaP degrader, we inoculated the probiotic strain into a well of BaP-coated $\mathrm{BH}$ minimal agar plate. Following 20 days of incubation, PMC10 showed a clear zone of degradation of $\mathrm{BaP}$ around the bacterial colony (Fig. 3B-II). Meanwhile, it did not result in a similar pattern on BH agar without $\mathrm{BaP}$ coating. These results further prove the ability of PMC10 to degrade polyaromatic hydrocarbons such as BaP.

PMC10 Mediated BaP Degradation in a Broth Culture Measured by ELISA

To re-evaluate the BaP degradation efficiency of PMC10, PMC10 was co-incubated with $100 \mathrm{ng} / \mathrm{ml} \mathrm{BaP} \mathrm{for}$ 20 days. Following incubation, the amount of $\mathrm{BaP}$ was measured using ELISA in control or PMC10-treated sample. In comparison with the control group, $\mathrm{PMC10}$ completely degraded $\mathrm{BaP}$ in the $\mathrm{BH}$ broth medium (Fig. 3C).

\section{Ability of PAH to Remove Live and Dead PMC10}

To check the ability of PMC10 to remove PAHs, two PAHs, namely naphthalene (Nap) and benzo(a)pyrene $(\mathrm{BaP})$, were selected. Live bacterial cells were mixed with each PAH at $10 \mu \mathrm{g} / \mathrm{ml}$ in PBS and the concentration of 

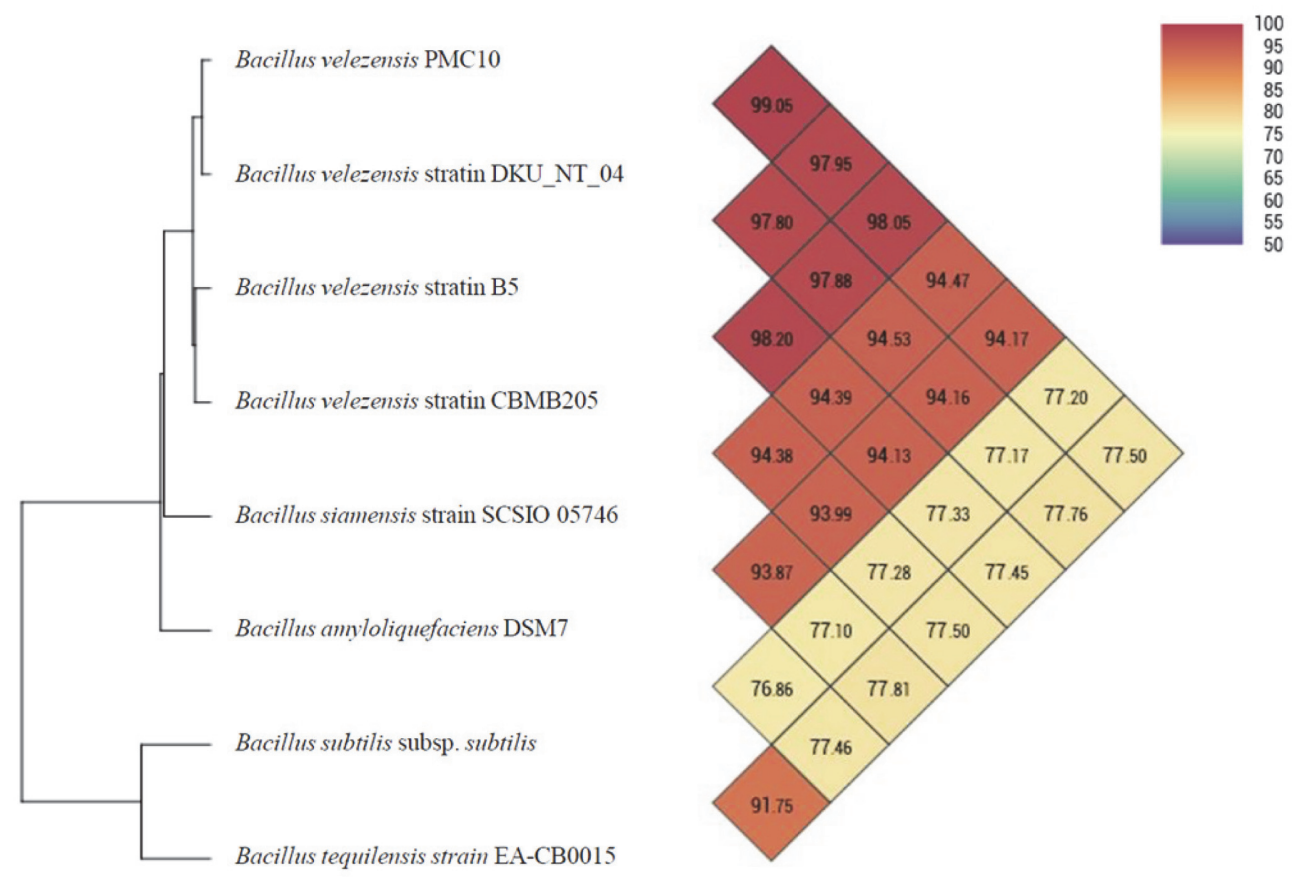

Fig. 2. Phylogenomic tree of the selected isolate based on available genomes of Bacillus species. Calculated values are used to determine species. If the value is greater than $96 \%$, it means that the strain belongs to the same species. The connecting point of diagonals departing from each strain shows the calculated OrthoANI value between two strains.

A

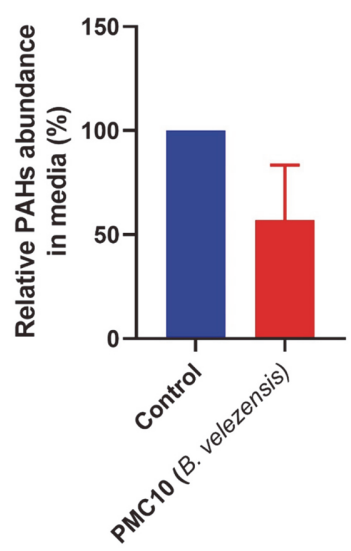

B

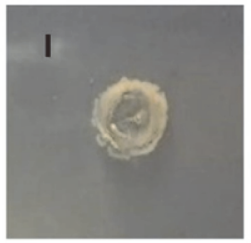

B. velezensis colony on without $\mathrm{BaP}$ containing $\mathrm{BH}$ agar plate

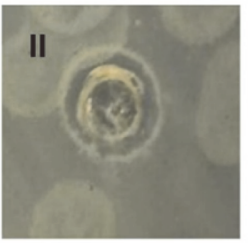

Clear zone around B. velezensis on BaP containing

$\mathrm{BH}$ agar plate
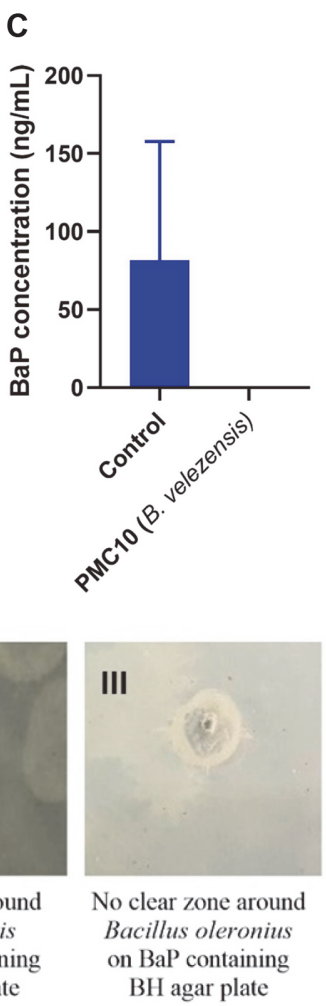

Fig. 3. Biodegradation of benzo(a)pyrene by $\boldsymbol{B}$. velezensis. (A) GCMS data representing relative BaP abundance in $\mathrm{BH}$ media following co-incubation with B. velezensis for 20 days. (B I) B. velezensis strain was inoculated onto BH agar plate without $\mathrm{BaP}$, showing no clear zone. (B II) B. velezensis formed a clear zone of degradation around the colony on BaPcontaining $\mathrm{BH}$ agar plate. (B III) No clear zone of degradation was formed around other bacteria tested on BaP-containing BH agar plates. (C) ELISA data showing BaP abundance in $\mathrm{BH}$ media following co-incubation with B. velezensis for 20 days. 
A

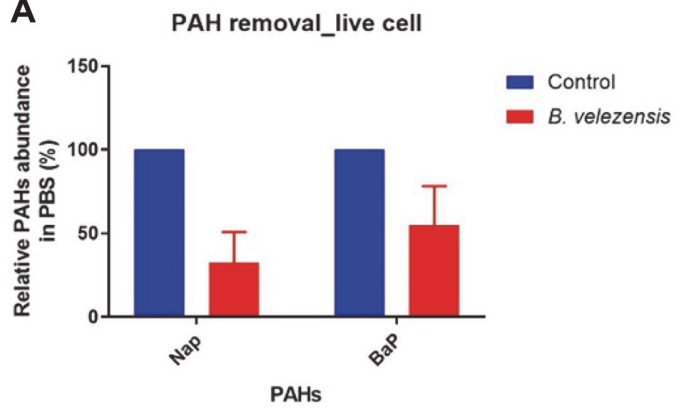

B PAH removal Heat killed cell

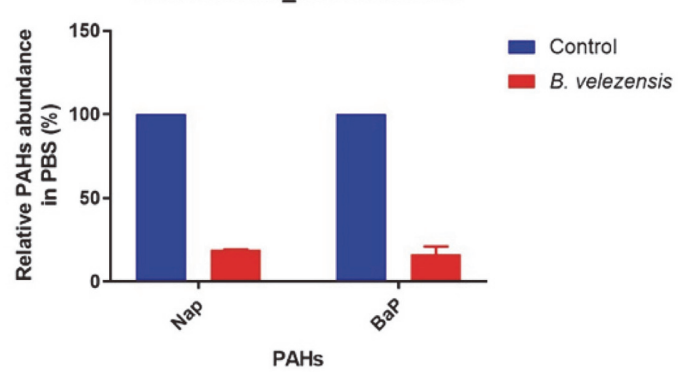

Fig. 4. Detoxification of benzo(a)pyrene and naphthalene by B. velezensis. (A) GCMS data showing relative abundance of Nap and BaP following live B. velezensis mediated removal in PBS. (B) GCMS data showing relative abundance of Nap and BaP following heat-killed B.subtilis mediated removal in PBS.

the PAH after removal was measured by GCMS analysis. Results showed that live PMC10 bacteria significantly reduced the amount of PAH in comparison with the control. Live PMC10 reduced $67.60 \%$ and $45.04 \%$ of the amount of dissolved Nap and BaP, respectively, by binding to PAH in comparison with the control group (Fig. 4A). Heat-killed PMC10 also significantly reduced aqueous PAH in comparison with the control group. Heat-killed PMC10 reduced $81.00 \%$ and $83.45 \%$ of the amount of dissolved Nap and BaP, respectively, by binding to PAH in comparison with the control group (Fig. 4B).

Relative Gene Expression Profile in Response to BaP Exposure

To gain insight into the possible mechanism involved in BaP degradation by PMC10, relative expression levels of RHD $\alpha$ and $\mathrm{HMBO}$ genes were investigated using real-time quantitative PCR.

In this experiment, an overgrown culture of PMC10 was treated with $20 \mu \mathrm{g} / \mathrm{ml} \mathrm{BaP}$ for a different time period. Data clearly showed that the expression of gene RHDa was upregulated in response to BaP treatment. In comparison with the control group $(0 \mathrm{~h})$, PMC10 increased the gene expression level of RHDa by 20.39 -fold $(p<$ $0.05)$ at $24 \mathrm{~h}$ after treatment. At $48 \mathrm{~h}$ after incubation, PMC10 increased RHDa gene expression by about 54.59fold $(p<0.01)$ (Fig. 5A). HBMO gene expression was also increased in response to BaP treatment. After $24 \mathrm{~h}$ of incubation, the expression of HBMO gene was not increased. However, after $48 \mathrm{~h}$ of incubation, gene expression was increased significantly by 5.31 -fold $(p<0.01)$ in comparison with the control group at $0 \mathrm{~h}$ (Fig. $5 \mathrm{~B})$.

\section{Cell Cytotoxicity of PMC10 to RAW 264.7 Macrophages and HDF Cells}

The cytotoxic effects of PMC10 at $10^{5}$ and $10^{7} \mathrm{CFU} / \mathrm{ml}$ on Raw 264.7 and HDF cells were examined using MTT assay. Results showed that PMC10 at $10^{7} \mathrm{CFU} / \mathrm{ml}$ was not cytotoxic to Raw 264.7 macrophages or HDF cells (Fig. 6).

\section{Anti-Inflammatory Activities of PMC10 Strains}

Nitric oxide (NO) is a pro-inflammatory mediator that can induce inflammation [28]. Therefore, in this experiment, the effects of live cell and cell-free supernatant of PMC10 on the production of NO in LPS-stimulated macrophages were investigated. In the case of live cells, $\sim 10^{5}$ and $\sim 10^{7} \mathrm{CFU} / \mathrm{ml}$ of PMC10 isolate significantly $(p<$

A

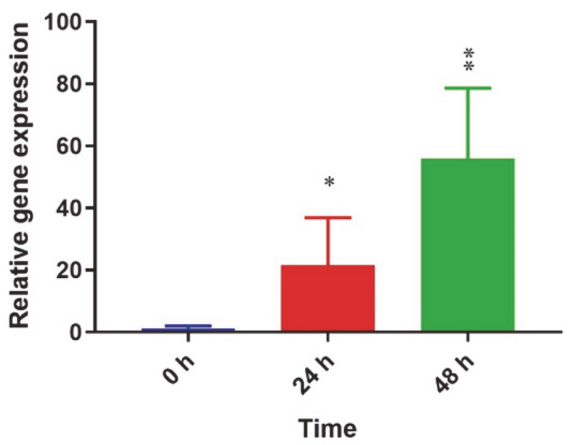

B

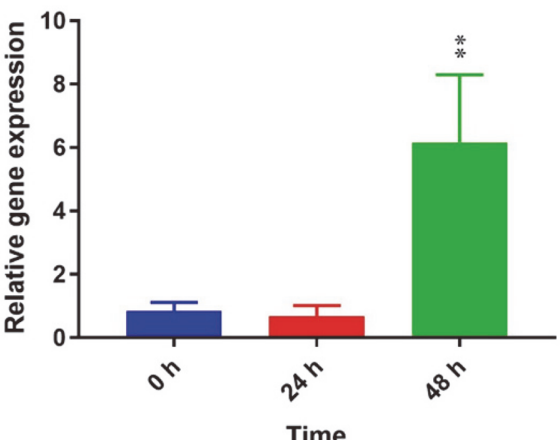

Fig. 5. Relative gene expression in B. velezensis in response to BaP. B. velezensis cells were co-incubated with $\mathrm{BaP}$. Induction of (A) RHDa, and (B) HBMO gene expression was studied by quantitative real-time PCR. Data are presented as mean \pm SD of three independent experiments done in triplicate. ${ }^{*} p<0.05 ;{ }^{* *} p<0.01$ by Student's $t$-test. 


\section{Cytotoxicity}

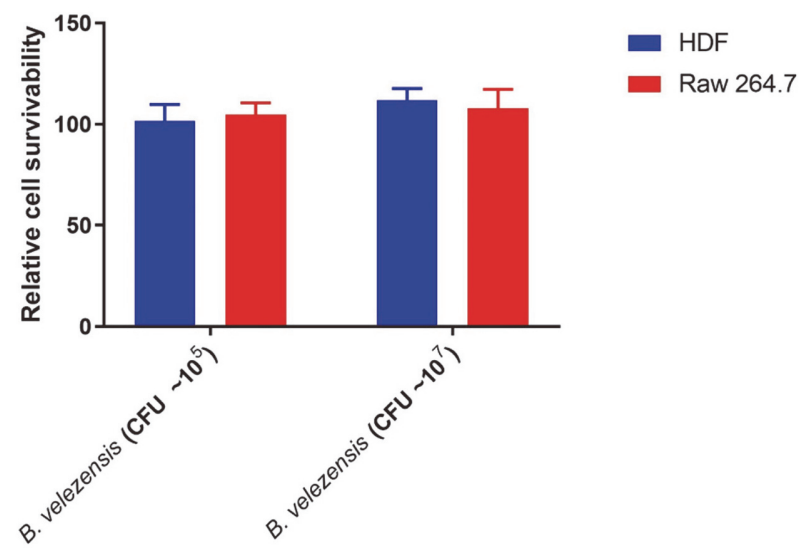

Fig. 6. Assay for cell cytotoxicity in human dendritic fibroblast (HDF) and RAW 264.7 cells. HDF and RAW 264.7 cell monolayers were treated with live B. velezensis. Relative viabilities of HDF and RAW 264.7 cells were measured using MTT assay.

0.0001) inhibited the production of NO. In this experiment, L-NMMA, a potent NO synthesis inhibitor, was used as a positive control. It also reduced the production of $\mathrm{NO}$ at a concentration up to $3.12 \mu \mathrm{g} / \mathrm{ml}(p<0.01)$ (Fig. $7 \mathrm{~A}$ ). In the case of cell-free supernatant, $10 \%$ and $20 \%$ CFS of PMC10 isolate significantly $(p<0.0001)$ inhibited the production of NO in LPS treated RAW 264.7 cells. Under this assay condition, $12.5 \mu \mathrm{g} / \mathrm{ml} \mathrm{L}-\mathrm{NMMA}$ also reduced the production of $\mathrm{NO}(p<0.05)$ (Fig. 7B).

\section{Antioxidative Activity of PMC10}

The antioxidative potential of PMC10 isolate was evaluated by performing DPPH-free radical scavenging assay. Cell-free supernatant of PMC10 isolate showed a potential free radical scavenging effect of $36.9 \%$ in comparison with the control group using DW instead of CFS. In this experiment, ascorbic acid (AA) was used as a positive control. AA at 100,10 , and $1 \mu \mathrm{g} / \mathrm{ml}$ showed scavenging effects of $65.74 \%, 63.47 \%$, and $53.79 \%$, respectively (Fig. 8). The cell-free extract of PMC10 isolate also exhibited potential DPPH free radical scavenging effect of $30.26 \%$ in comparison with the control group. Here, 100,10 , and $1 \mu \mathrm{g} / \mathrm{ml}$ of AA as a positive control showed scavenging effects of $62.18 \%, 59.90 \%$, and $48.85 \%$, respectively (Fig. 8).

A

Anti-inflammation-live cell

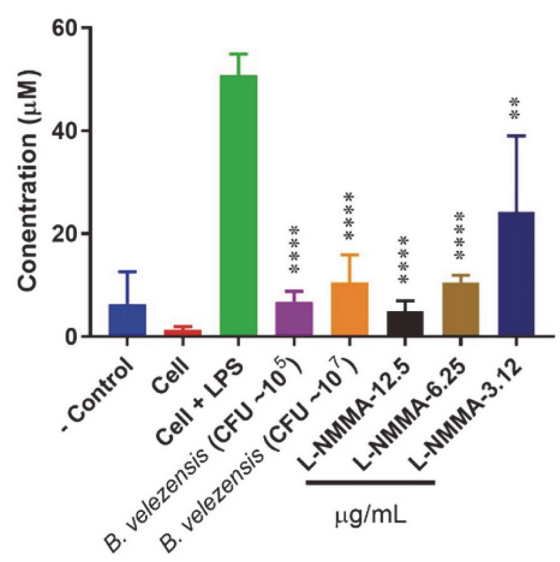

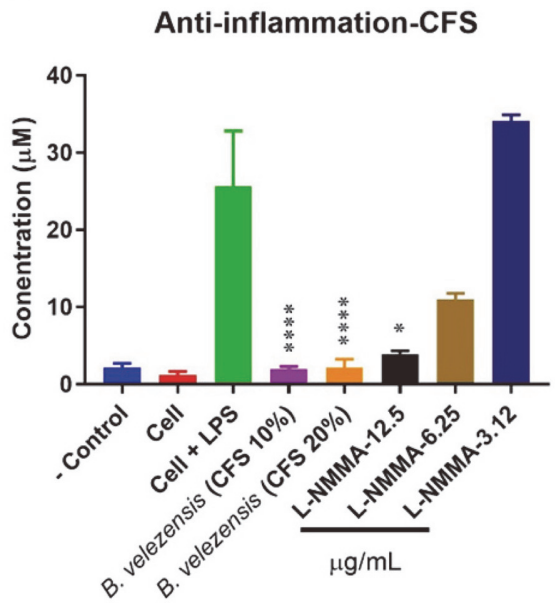

Fig. 7. Modulation of LPS-induced NO production by live B. velezensis and cell-free supernatant of $B$. velezensis in LPS-treated macrophages. RAW 264.7 macrophages were treated with LPS at a concentration of 2,000 ng/ $\mathrm{ml}$. The production of $\mathrm{NO}$ was measured following treatment with (A) live B. velezensis or (B) cell-free supernatant of B. velezensis. Data are presented as mean $\pm \mathrm{SD}$ of three independent experiments done in triplicate. ${ }^{*} p<0.05 ;{ }^{* *} p<0.01 ;{ }^{* * *} p<$ 0.001 ; and ${ }^{* * *} p<0.0001$ by Student's $t$-test. L-NG-monomethyl arginine acetate (L-NMMA) was used as a positive control. 
Anti-oxidation

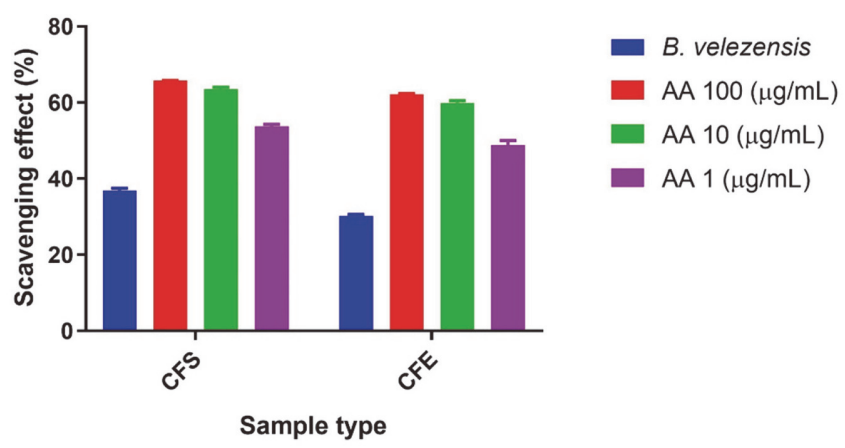

Fig. 8. Free radical scavenging effects of cell-free supernatant (CFS) and cell-free extract (CFE) of $B$. velezensis. DPPH-free radical scavenging effect of ascorbic acid (AA) as a positive control was also measured.

\section{Discussion}

Polycyclic aromatic hydrocarbons (PAHs) such as naphthalene, benzo(a)pyrene, pyrene, fluorine, and so on are omnipresent environmental pollutants that are generally produced by inadequate combustion of organic materials such as coal, wood, oil, and petrol [9]. Other major sources of PAHs include motor vehicle exhaust, residential heating, coke and aluminum production industry, and petroleum refineries [9].

PAHs are highly toxigenic, carcinogenic, and mutagenic in nature [29]. Long-term exposure to gaseous or particulate PAH mixtures in the air can lead to severe health problems such as skin cancer [5], digestive tract cancer [30], cardiovascular disease, fatal ischemic heart disease, heart rate variability, hypertension, inflammation, atherosclerosis, and asthma [31].

Therefore, finding a safe and effective option to degrade and/or remove PAHs from the human body is urgently needed. Recently, scientists are very interested in xenobiotic-degrading microorganisms for bioremediation and removal of toxic chemicals [32].

To this end, we have chosen probiotic bacteria isolated from different Korean fermented foods as ideal candidates to degrade and/or remove PAHs. By definition, probiotics are live bacteria that confer a significant health benefit to consumers or hosts [33]. Probiotics are used for the improvement of intestinal health, immune response, reduction of serum cholesterol, prevention of cancer, treatment of acute or antibiotic-associated diarrhea, improvement of lactose metabolism, and so on [10]. In addition, probiotic bacteria are used for detoxifying xenobiotics and adsorbing toxic molecules by physical interactions [1].

In this study, we selected benzo(a)pyrene $(\mathrm{BaP})$ as a representative $\mathrm{PAH}$ compound because $\mathrm{BaP}$ is a carcinogenic compound that has been comprehensively studied and classified by the IARC as a Group 1 carcinogen [5]. We also selected naphthalene, another common pollutant, because it has been frequently used as a chemical model to study the degradation of PAHs [16].

To find a prospective probiotic candidate with potential BaP-degrading efficacy, we chose a total of 26 fermented foods and co-incubated them with $\mathrm{BaP}$ at $250 \mathrm{mg} / \mathrm{l}$ for 5 times of 7-day successive incubation in Bushnell Haas minimal broth. Following incubation, bacterial culture was spread onto NA agar plates, and colonies with distinct morphologies were selected for further studies. Since the BH media contained $\mathrm{BaP}$ as the sole carbon source, live bacteria in this condition could have the ability to degrade $\mathrm{BaP}$ to get essential energy. Initially, we isolated five distinct colonies: PMC1, PMC2, PMC3, PMC10, and PMC12. Based on 16S rRNA gene sequencing, $\mathrm{PMC10}$ was identified as Bacillus velezensis. Comparative whole genome sequencing analysis also revealed the identity of PMC10 as B. velezensis. All bacterial isolates were co-incubated with $\mathrm{BaP}$ separately in $\mathrm{BH}$ medium to check their BaP-degrading efficacies. GCMS analysis data revealed that isolate PMC10 showed the highest potential $\mathrm{BaP}$ degradation efficacy $(51.32 \%)$ in comparison with the control group excluding bacteria. To validate this GCMS analysis result, the strain PMC10 was inoculated on a $\mathrm{BaP}$-coated $\mathrm{BH}$ agar plate to observe its degradation efficacy on agar condition. In the BaP-containing agar plate, $\mathrm{PMC} 10$ isolate degraded $\mathrm{BaP}$ around the bacterial colony and formed a clear zone. Degradation of BaP by PMC10 was also measured by ELISA. Results showed complete degradation of $\mathrm{BaP}(100 \mathrm{ng} / \mathrm{ml})$ in comparison with the control group. These results suggest that PMC10 is a promising probiotic candidate with potential PAH degradation efficacy. In a previous study, Paracoccus yeei, Acinetobacter lwoffii, Micrococcus luteus, Staphylococcus caprae, Pseudomonas oleovorans, and Bacillus licheniformis have shown potential BaP-degrading efficacy [6]. Pseudomonas aeruginosa also shows degradation efficacy against Nap [16]. LAB have also been reported as potential probiotics to degrade different $\mathrm{PAH}$, including $\mathrm{BaP}$ and Nap [12].

It has been reported that PAH ring-hydroxylating dioxygenases (PAH-RHDalpha) and 4-hydroxybenzoate 3monooxygenase (HBMO) are involved in the initial step of aerobic metabolism of PAH [17,34]. To gain insight into the mechanism of $\mathrm{BaP}$ degradation by $\mathrm{PMC10}$, we performed gene expression profiling in response to $\mathrm{BaP}$ using two sets of primers, RHDa and HBMO. Strain PMC10 clearly induced RHDa gene expression after incubating with $\mathrm{BaP}$ for $24 \mathrm{~h}$ and $48 \mathrm{~h}$. HBMO gene was also induced following $48 \mathrm{~h}$ of incubation. In another study, RHDa and HBMO gene expression levels were found to be increased in Novosphingobium pentaromativorans 
US6-1 in the presence of $\mathrm{BaP}[17]$. These results suggest that the degradation of $\mathrm{BaP}$ can be accomplished by ringhydroxylating dioxygenase-initiated metabolic pathway. A previous study also suggested that this pathway enters the tricarboxylic acid (TCA) cycle [17].

In addition to biodegradation, we were also interested in the removal of PAHs such BaP and Nap by isolate PMC10. We co-incubated bacteria with $\mathrm{BaP}$ and Nap. Following centrifugation, the removal effect was compared with the control group excluding bacteria. Bacterial number and $\mathrm{pH}$ of the media were selected based on a previous study [1]. GCMS analysis results suggested that live PMC10 was capable of removing BaP (45.05\% reduction) and Nap (67.61\% reduction) significantly. Heat-killed PMC10 was also capable of removing BaP (83.45\% reduction) and Nap (81.00\% reduction) in comparison with the control group. These data suggest that PMC10 is a prospective candidate to detoxify food or skin PAH contamination. A previous study has shown that lactic acid bacteria such as Bifidobacterium lactis, Lactobacillus acidophilus, Lactobacillus bulgaricus, and Streptococcus thermophilus have potential BaP removal efficacy [1]. Other studies have also examined the potential of probiotic bacteria to remove food-induced toxicants, mycotoxins, and heavy metals [35-37].

Although PMC10 was isolated from fermented food, to evaluate its safety further, we checked its toxicity to RAW 264.7 macrophages and human dermal fibroblasts. Cell viability data suggested that live bacteria of strain PMC10 at $\sim 10^{5}$ and $\sim 10^{7} \mathrm{CFU} / \mathrm{ml}$ were not cytotoxic to RAW 264.7 macrophages or HDF cells. As PAHs are potential skin carcinogenic agents [5], we therefore tested dermal fibroblast cells to determine the possible scope in utilizing the strain PMC10 to degrade skin PAHs.

In addition, various functional properties such as anti-inflammation and anti-oxidation effect of the selected strain were investigated. Nitric oxide is a crucial marker in inflammatory disease. Therefore, the effects of PMC10 live cells and cell-free supernatant on NO production in LPS-treated RAW 264.7 macrophages were studied. Both live bacteria and cell-free supernatant of PMC10 showed significant anti-inflammatory effects by lowering NO production. L-NG-monomethyl arginine acetate (L-NMMA), a nitric oxide synthase inhibitor [38], was used in this study as a positive control. Interestingly, PMC10 showed better efficacy than $6.25 \mu \mathrm{g} / \mathrm{ml}$ L-NMMA. A previous study also reported that different probiotics such as Lactobacillus acidophilus, Lactobacillus casei, Lactococcus lactis, Lactobacillus reuteri, L. rhamnosus GG, and Saccharomyces boulardii have potential antiinflammatory activities [39].

In addition, cell-free supernatant and cell-free extract of PMC10 showed potential radical scavenging activities. Ascorbic acid, a well-known free radical scavenger [40], was used as a positive control in this study. The antioxidative effect of PMC10 was comparable to that of ascorbic acid. Some probiotics have the ability to reduce oxidative damage by scavenging free radicals or by modulating activities of crucial antioxidative enzymes. Thus, cells can be protected from carcinogen-induced damage [41]. Bifidobacterium longum, Lactobacillus acidophilus, and Lactobacillus rhamnosus have been reported to possess potential antioxidative effects [42].

Altogether, our results suggest that $B$. velezensis is safe, and our study also highlights the potential application of B. velezensis as a probiotic to degrade or detoxify PAHs in the human gut or skin. Further studies are required to purify responsible enzymes, which can be formulated as cosmetics in the future to detoxify PAH on human skin. Besides, our study showed that along with the PAH degradation efficacy, B. velezensis has anti-oxidation and antiinflammatory potential, which will benefit human cells during application.

\section{Acknowledgments}

This research was financially supported by the Ministry of Trade, Industry, and Energy (MOTIE), Korea, under the "Regional Industry-based Organization Support Program" (Ref. No. P0001942) supervised by the Korea Institute for Advancement of Technology (KIAT). This study was also supported by Soonchunhyang University Research Fund. We want to thank all the lab members for their support during this study.

\section{Conflict of Interest}

The authors have no financial conflicts of interest to declare.

\section{References}

1. Yousefi M, Shariatifar N, Tajabadi Ebrahimi M, Mortazavian AM, Mohammadi A, Khorshidian N, et al. 2019. In vitro removal of polycyclic aromatic hydrocarbons by lactic acid bacteria. J. Appl. Microbiol. 126: 954-964.

2. Okai M, Kihara I, Yokoyama Y, Ishida M, Urano N. 2015. Isolation and characterization of benzo [a] pyrene-degrading bacteria from the Tokyo Bay area and Tama River in Japan. FEMS Microbiol. Lett. 362: fnv143.

3. Abou-Arab AAK, Salim A-B, Maher RA, El-Hendawy HH, Awad AA. 2010. Degradation of polycyclic aromatic hydrocarbons as affected by some lactic acid bacteria. J. Am. Sci. 6: 1237-1246.

4. Kim K-H, Jahan SA, Kabir E, Brown RJC. 2013. A review of airborne polycyclic aromatic hydrocarbons (PAHs) and their human health effects. Environ. Int. 60: 71-80.

5. Siddens LK, Larkin A, Krueger SK, Bradfield CA, Waters KM, Tilton SC, et al. 2012. Polycyclic aromatic hydrocarbons as skin carcinogens: comparison of benzo [a] pyrene, dibenzo [def, p] chrysene and three environmental mixtures in the FVB/N mouse. Toxicol. Appl. Pharmacol. 264: 377-386.

6. Sowada J, Schmalenberger A, Ebner I, Luch A, Tralau T. 2014. Degradation of benzo [a] pyrene by bacterial isolates from human skin. FEMS Microbiol. Ecol. 88: 129-139.

7. Program NT. 2000. Toxicology and carcinogenesis studies of naphthalene in F344/N rats. US Dep. Heal. Hum. Serv. Natl. Toxicol. Program, Washington, DC ., USA.

8. Karami S, Boffetta P, Brennan P, Stewart PA, Zaridze D, Matveev V, et al. 2011. Renal cancer risk and occupational exposure to polycyclic aromatic hydrocarbons and plastics. J. Occup. Environ. Med. 53: 218-223.

9. Abdel-Shafy HI, Mansour MSM. 2016. A review on polycyclic aromatic hydrocarbons: source, environmental impact, effect on human health and remediation. Egypt J. Pet. 25: 107-123. 
10. Kechagia M, Basoulis D, Konstantopoulou S, Dimitriadi D, Gyftopoulou K, Skarmoutsou N, et al. 2013. Health benefits of probiotics: a review. ISRN Nutr. 2013: 481651 .

11. Rajendran R, Ohta Y. 1998. Binding of heterocyclic amines by lactic acid bacteria from miso, a fermented Japanese food. Can J. Microbiol. 44: 109-115.

12. Abou-Arab AAK, Abou-Bakr S, Maher RA, El-Hendawy HH, Awad AA. 2015. Persistence of some lactic acid bacteria as affected by polycyclic aromatic hydrocarbons. J. Microbiol. Exp. 2: 1-6.

13. Dominici L, Villarini M, Trotta F, Federici E, Cenci G, Moretti M. 2014. Protective effects of probiotic Lactobacillus rhamnosus IMC501 in mice treated with PhIP. J. Microbiol. Biotechnol. 24: 371-378.

14. Rafter J. 2004. The effects of probiotics on colon cancer development. Nutr. Res. Rev. 17: 277-284.

15. Boffetta P, Jourenkova N, Gustavsson P. 1997. Cancer risk from occupational and environmental exposure to polycyclic aromatic hydrocarbons. Cancer Causes Control 8: 444-472.

16. Karimi B, Habibi M, Esvand M. 2015. Biodegradation of naphthalene using Pseudomonas aeruginosa by up flow anoxic-aerobic continuous flow combined bioreactor. J. Environ. Health Sci. Eng. 13: 26.

17. Lyu Y, Zheng W, Zheng T, Tian Y. 2014. Biodegradation of polycyclic aromatic hydrocarbons by Novosphingobium pentaromativorans US6-1. PLoS One 9: e101438.

18. Bogardt AH, Hemmingsen BB. 1992. Enumeration of phenanthrene-degrading bacteria by an overlayer technique and its use in evaluation of petroleum-contaminated sites. Appl. Environ. Microbiol. 58: 2579-2582.

19. Oyehan TA, Al-Thukair AA. 2017. Isolation and characterization of PAH-degrading bacteria from the Eastern Province, Saudi Arabia. Mar. Pollut. Bull. 115: 39-46.

20. Kim S, Seo H, Mahmud H Al, Islam MI, Sultana OF, Lee Y, et al. 2020. Melanin Bleaching and melanogenesis inhibition effects of Pediococcus acidilactici PMC48 isolated from Korean Perilla Leaf Kimchi. J. Microbiol. Biotechnol. 30: 1051-1059.

21. Petti CA. 2008. Interpretive criteria for identification of bacteria and fungi by DNA target sequencing. Clinical and Laboratory Standards Institute.

22. Shen Q, Shang N, Li P. 2011. In vitro and in vivo antioxidant activity of Bifidobacterium animalis 01 isolated from centenarians. Curr. Microbiol. 62: 1097-1103.

23. Kim M, Chun J. 2014. 16S rRNA gene-based identification of bacteria and archaea using the EzTaxon server. Methods Microbiol. 41: $61-74$.

24. Janda JM, Abbott SL. 2007. 16S rRNA gene sequencing for bacterial identification in the diagnostic laboratory: pluses, perils, and pitfalls. J. Clin. Microbiol. 45: 2761-2764.

25. Tatusov RL, Galperin MY, Natale DA, Koonin E V. 2000. The COG database: a tool for genome-scale analysis of protein functions and evolution. Nucleic Acids Res. 28: 33-36.

26. Lee I, Kim YO, Park S-C, Chun J. 2016. OrthoANI: an improved algorithm and software for calculating average nucleotide identity. Int. J. Syst. Evol. Microbiol. 66: 1100-1103.

27. Aubin GG, Bémer P, Kambarev S, Patel NB, Lemenand O, Caillon J, et al. 2016. Propionibacterium namnetense sp. nov., isolated from a human bone infection. Int. J. Syst. Evol. Microbiol. 66: 3393-3399.

28. Mahmud HA, Seo H, Kim S, Islam MI, Nam K-W, Cho H-D, et al. 2017. Thymoquinone (TQ) inhibits the replication of intracellular Mycobacterium tuberculosis in macrophages and modulates nitric oxide production. BMC Complement. Altern. Med. 17: 1-8.

29. Haritash AK, Kaushik CP. 2009. Biodegradation aspects of polycyclic aromatic hydrocarbons (PAHs): a review. J. Hazard Mater. 169: 1-15.

30. Diggs DL, Huderson AC, Harris KL, Myers JN, Banks LD, Rekhadevi P V, et al. 2011. Polycyclic aromatic hydrocarbons and digestive tract cancers: a perspective. J. Environ. Sci. Health C Environ. Carcinog. Ecotoxicol. Rev. 29: 324-357.

31. Poursafa P, Moosazadeh M, Abedini E, Hajizadeh Y, Mansourian M, Pourzamani H, et al. 2017. A systematic review on the effects of polycyclic aromatic hydrocarbons on cardiometabolic impairment. Int. J. Prev. Med. 8: 19

32. Samanta SK, Singh O V, Jain RK. 2002. Polycyclic aromatic hydrocarbons: environmental pollution and bioremediation. Trends Biotechnol. 20: 243-248.

33. Fijan S. 2014. Microorganisms with claimed probiotic properties: an overview of recent literature. Int. J. Environ. Res. Public Health 11: 4745-4767.

34. Yun SH, Choi C-W, Lee S-Y, Lee YG, Kwon J, Leem SH, et al. 2014. Proteomic characterization of plasmid pLA1 for biodegradation of polycyclic aromatic hydrocarbons in the marine bacterium, Novosphingobium pentaromativorans US6-1. PLoS One 9: e90812.

35. Sangsila A, Faucet-Marquis V, Pfohl-Leszkowicz A, Itsaranuwat P. 2016. Detoxification of zearalenone by Lactobacillus pentosus strains. Food Control 62: 187-192.

36. Ismail A, Levin RE, Riaz M, Akhtar S, Gong YY, de Oliveira CAF. 2017. Effect of different microbial concentrations on binding of aflatoxin M1 and stability testing. Food Control 73: 492-496.

37. Sarlak Z, Rouhi M, Mohammadi R, Khaksar R, Mortazavian AM, Sohrabvandi S, et al. 2017. Probiotic biological strategies to decontaminate aflatoxin M1 in a traditional Iranian fermented milk drink (Doogh). Food Control 71:152-159.

38. Mahmud H Al, Seo H, Kim S, Islam MI, Nam K-W, Cho H-D, et al. 2017. Thymoquinone (TQ) inhibits the replication of intracellular Mycobacterium tuberculosis in macrophages and modulates nitric oxide production. BMC Complement. Altern. Med. 17: 279.

39. De Marco S, Sichetti M, Muradyan D, Piccioni M, Traina G, Pagiotti R, et al. 2018. Probiotic cell-free supernatants exhibited antiinflammatory and antioxidant activity on human gut epithelial cells and macrophages stimulated with LPS. Evid. Based Complement. Altern. Med. 2018: 1756308.

40. Nimse SB, Pal D. 2015. Free radicals, natural antioxidants, and their reaction mechanisms. Rsc. Adv. 5: 27986-28006.

41. Mishra V, Shah C, Mokashe N, Chavan R, Yadav H, Prajapati J. 2015. Probiotics as potential antioxidants: a systematic review. J. Agric. Food Chem. 63: 3615-3626.

42. El-Nawawy MA, El-Malkey W, Aumara IE. 2009. Production and properties of antioxidative fermented probiotic beverages with natural fruit juices. Ann. Agric. Sci. 54: 121-135.

43. Grady EN, MacDonald J, Ho MT, Weselowski B, McDowell T, Solomon O, et al. 2019. Characterization and complete genome analysis of the surfactin-producing, plant-protecting bacterium Bacillus velezensis 9D-6. BMC Microbiol. $19: 5$.

44. Silva F de J, Ferreira LC, Campos VP, Cruz-Magalhães V, Barros AF, Andrade JP, et al. 2019. Complete genome sequence of the biocontrol agent Bacillus velezensis UFLA258 and its comparison with related species: diversity within the commons. Genome Biol. Evol. 11:2818-2823.

45. Choi J, Nam J, Seo M-H. 2021. Complete genome sequence of Bacillus velezensis NST6 and comparison with the species belonging to operational group B. amyloliquefaciens. Genomics 113: 380-386

46. Liu H, Zeng Q, Wang W, Zhang R, Yao J. 2020. Complete genome sequence of Bacillus velezensis strain AL7, a biocontrol agent for suppression of cotton Verticillium wilt. Microbiol. Resour. Announc. 9: e 015959-19. 